SEBőK SZILÁRd

Comenius Egyetem, Pozsony

szilardsebok@gmail.com

\title{
PERSPEKTÍVÁK KÜLÖNBÖZŐSÉGE A NYELVLEÍRÁSBAN ${ }^{1}$
}

\section{Bevezetés}

A „nyelv” és „metanyelv” fogalmak bejáratott kategóriáknak számítanak a nyelvészetben, amelyek meghatározásával nem szokás külön foglalkozni. Ezek meghatározása könnyen fellapozható a nyelvészeti enciklopédiákban (1. pl. Mistrík et al. 1993: 269; Crystal 2008: 302) vagy épp a fogalompár viszonyát elemző, áttekintő tanulmányokban (Jaworski et al. 2004; Coupland-Jaworski 2004). Nagy általánosságban viszont az látszik, hogy a legtöbb nyelvészeti és metanyelvészeti munka ott kezdődik, ahol ennek a két fogalomnak a meghatározására már nincs szükség, mert az - mintegy hallgatólagos tudásként - mélyen ott gyökerezik a nyelvészeti alapismeretek között.

A nyelv fogalma esetében lehet találni olyan nyelvészeti munkákat, amelyek alapjaiban kérdőjelezik meg a fogalmat, és ennek fiktív jellegére irányítják rá a figyelmet (l. Jørgensen et al. 2011: 29; vö. Szilágyi N. 2011; Lanstyák 2017: 49-50), vagy a kategória kultúraspecifikus (Gal 2006:14), illetve ideológiai jellegét hangsúlyozzák (Sebők 2017: 42-47). A metanyelv fogalma kapcsán ugyanakkor nehéz az előbbihez hasonló, kritikai szellemben fogant írásokat találni. A témával kapcsolatos munkák (Jakobson 1956/1985; Van Leeuwen 2004: 107-108; Preston 2004: 75-101) sem annyira a kategória problémáival, mint inkább a meghatározás kérdéseivel foglalkoznak - lényegében azzal, hogy szűkebbre vagy tágabbra legyen-e „szabva” a metanyelv definíciója (a kérdésről részletesen 1. Sebők 2017: 60-66). Ez nem meglepő, hiszen ez a fogalom nem ágyazódik be olyan szervesen a beszélők életébe, mint a nyelvé, és mivel a metanyelv kategóriájának a létrehozása a tudománynak, pontosabban a logika tudományának a vívmánya, ehhez sokkal kevesebb nyelvi ideológia kapcsolódik, mint a nyelv fogalmához.

A metanyelvi szint megkülönböztetése a logikában a logikai paradoxonok megoldásánál vált szükségessé (vö. Smullyan 1986: 189), a nyelvészetben pedig szintén nagy hasznot hozott az általában vett beszédtevékenység és az erről szóló beszéd elkülönítése, hiszen a kommunikáció egy új aspektusát hozta napvilágra. Jakobson rá is mutatott, hogy a beszédről szóló beszéd, vagyis a metanyelvi szint az, amely „lehetővé teszi”

1 Ezt a munkát a Kutatás- és Fejlesztéstámogató Ügynökség támogatta az APVV-17-0254 sz. szerződés keretében. Itt köszönöm meg Lanstyák István értékes megjegyzéseit, amelyeket a tanulmány előző változatához füzött. 
a kommunikáló feleknek, hogy ellenőrizzék, vajon a másik fél intenciója szerint értették-e meg a hallottakat (1956/1985: 117). Ez az a szint, amely a nyelvre vagy ennek valamely aspektusára irányítja a beszélők figyelmét beszéd közben (1. Preston 2004: 75-76, 86), illetve amely a különféle nyelvalakító tevékenységek alapját képezi (vö. Lanstyák 2014: 9-10). A metanyelvi szint elkülönítésének hasznosságát tehát kár lenne tagadni. Sokkal inkább azzal érdemes foglalkozni, hogy mi az, amit a nyelv és metanyelv kategóriák szembeállítása és a hozzá kapcsolódó nyelvészeti modell - a maga előnyei mellett - úgymond eltakar előlünk.

Egy korábbi munkámban (Sebők 2017) részletesen foglalkoztam azzal a kérdéssel, hogy mit jelent a metanyelv fogalma (i. m. 48-68), illetve megpróbáltam felvázolni a nyelv és metanyelv viszonyát, valamint a metaszintek hierarchikus modelljét (Sebők 2017: 78-86). Ezzel a vázlattal azt összegeztem, hogy mind a hétköznapi beszélők, mind a nyelvészek különböző metaszinteken foglalkozhatnak a nyelvvel kapcsolatos kérdésekkel, attól függően, hogy mi az, amit a közlendőjük tárgyává akarnak tenni: hogy a nyelvről van-e szó, a nyelvről szóló megnyilatkozásokról vagy ez utóbbiakkal kapcsolatos, metanyelvi jellegủ megnyilatkozásokról, netán egy olyan diskurzusról, amely az említett metanyelvi jellegủ megnyilatkozásokat értékeli egy „magasabb” metanyelvi szinten. Ezzel arra próbáltam rámutatni, hogy a metanyelv kategóriája nem csupán a nyelv: metanyelv szembenállás egyik felét jelenti, hanem a különböző metaszintek dinamikus váltakozását is.

Ez a modell jól szemléltette a metaszintek sokféleségét, ugyanakkor nem sokat árult el arról, hogy egyetlen metaszinten belül is többféle perspektíva váltakozhat. Ezek a perspektívák azonban már nem azon alapulnak, hogy mi az, amit a megnyilatkozás vagy leírás tárgyává akarunk tenni, hanem azon, hogy - mondjuk úgy - milyen perspektívákból „,szervezzük" meg a leírásunkat (metanyelvi szinttől függetlenül). Az egyes perspektívák megkülönböztetése kapcsán azt a kérdést tehetjük fel, hogy vajon a nyelvész miként pozicionálja magát a nyelv leírásakor; melyik az a perspektíva, amelyből a nyelvi valóság valamely szeletét leírja. A korábbi kutatásaim alapján négy olyan leírói perspektívát különítettem el, amely befolyásolja a nyelvleírás módját, azaz a nyelvészek metanyelvét: a beszélőét, a kutatóét, a szerzőét és a „terminusokét” (Sebők 2017: 152). Az alábbiakban ezeket fogom bemutatni.

\section{A beszélő perspektívája}

Kezdjük a beszélő perspektívájával. Ebben az esetben a nyelvész a beszélő szemszögéből közelíti meg a leírás tárgyát, és az ő nyelvi viselkedését akarja jobban megérteni, amelyen keresztül - mintegy másodlagosan - a nyelvi valóság jobb megértéséhez járul hozzá. Azért csak másodlagosan, mert az érdeklődésének a fókuszában nem egy lehetséges nyelvivalóság-magyarázat kiegészítése, megerősítése vagy megkérdőjelezése áll (ilyet a beszélői perspektívából nehéz is lenne elképzelni), hanem a beszélők - nevezzük így: - beszélési stratégiái, amelyekkel azok biztosítani tudják, hogy a közlendőjük a legjobb tudásuknak és a szándékuknak megfelelően hangozzon el. 
Ha a nyelvész a beszélő perspektívájából végzi a leírását, akkor - mondjuk így: a beszélő „bőrébe bújik”, és főleg a saját kommunikációs tapasztalatai, illetve a nyelvészeti áttekintése alapján magyarázza, hogy az adott megnyilatkozás miért úgy ment végbe, ahogyan azt láttuk vagy hallottuk. Esetleg: mi történt volna, ha a beszélő más módon fejezte volna ki magát. A kiindulópont az, hogy a beszélő tudja a legjobban, hogy mit miért csinál (vagyis nem az a kérdés, mit hogyan kellene mondania), viszont a legtöbb esetben - nem rendelkezik olyan következetes nyelvészeti fogalmi apparátussal, amely lehetővé tenné, hogy elmagyarázza a saját nyelvi viselkedését. ${ }^{2}$ A nyelvész az, aki mivel egyúttal beszélő is - meg tudja fogalmazni ezeket a magyarázatokat. Ha a magyarázat összhangban van a „beszélő perspektívájával”, illetve azzal, hogy a beszélők hogyan értik meg egymást, akkor ezt a beszélő oldaláról egy a problémamegoldás pszichológiájából ismert ún. aha-élmény is kíséri (l. Woodworth-Schlosberg 1959: 874; Tóth 2007: 253; vö. Szilágyi N. 2013: 238, 2. lábjegyzet), vagyis egy olyan hirtelen belátás, amely során a beszélő mintha azt mondaná: „aha, ez tényleg így lehet, csak én ezt nem tudtam volna így megfogalmazni".

A beszélői perspektívából történő leírás érzékeltetésére Szilágyi N. Sándortól választottam egy idézetet, amely a határozatlan névelö használatáról szól:

(1) Jancsi azzal kezdte: vettem egy autót. Így mondta, határozatlan névelővel. Biztosan nem azért mondta így, mert az ő számára az még mindig valami ismeretlen vagy határozatlan dolog. Nagyon is pontosan tudja róla, melyik az, hol van, milyen, szinte látja maga elött, hiszen egy fél délelőttöt csak vele babrálva töltött el, próbálgatta mindenét. Úgy ismeri már, mintha egy hónapja járna vele. Ez tehát nem lehet magyarázata a határozatlan névelö használatának. Nem is a maga szempontjából mondta ő ezt most határozatlanul, hanem Juliskára, a hallgatóra való tekintettel: őt akarta megkímélni attól, hogy most elkezdje visszapörgetni az agyában korábbi közös élményeiket és beszélgetéseiket, hogy kitalálja valahogy, melyik autóra is gondolhat most Jancsi. A határozatlan névelővel ugyanazt mondja itt Jancsi Juliskának, mintha azt mondaná: „Ne is próbáld kitalálni, hogy a világ rengeteg autója közül melyik az az egy, amelyikről én most éppen beszélek, mert én jól tudom, hogy neked nincs honnan tudnod, melyikről beszélek!” És számít is rá, hogy Juliska az egy-ből pontosan ezt fogja érteni. (Szilágyi N. 2004: 17, kiemelések az eredeti szövegben)

Az idézetet még hosszan folytathatnánk, de ahhoz, hogy észrevegyük a perspektíva legfőbb jellemzőit ezzel a részlettel is beérhetjük. A föntebb leírt jellemzőkön kívül talán

2 Vö. olyan kijelentésekkel, mint: „ismerem a szót, tudom mit jelent, de nem tudom elmondani”; vagy két szinonima kapcsán: „érzem a kettő közötti különbséget, példát is tudok mondani, hogy hol melyiket használom, de nem tudom megmondani, mi a különbség" stb. 
a legfeltűnőbb jelenség, hogy Szilágyi N. egy személynevet használ, amikor a beszélőről ír, jelezve, hogy konkrét beszélőről van szó, aki ha tehetné, nagyjából ugyanígy mondaná el, hogy milyen megfontolásból használt határozatlan névelöt az autóvásárlással kapcsolatban. Ugyanakkor: mint azt Szilágyi N. a könyve egy másik helyén leírja (2004: 68), valójában az említett esetben nem egy - a szó szoros értelemében vett - megfigyelésről van szó, mert Jancsit csupán elképzeltük, a leírás mégis olyan benyomást kelt, mely szerint Jancsi akár létezhetne is. Vagyis: a leírás nem egy konkrét, azaz egyéni szociolingvisztikai jellemzőkkel rendelkező beszélő megfigyelésének az eredményét összegzi, hanem úgy szól egy elképzelt személyről, hogy a vele kapcsolatos megállapítások általános érvényt nyernek, és ezek alapján bármely magyar nyelvű beszélő ráismerhet saját „beszélési stratégiáira”. Az „elképzelt” kifejezés tehát itt nem egy elvont beszélőt jelent, akit különféle tulajdonságok absztrahálásával hozunk létre a képzeletünkben, hanem egy olyan beszélőt, akinek az adatait ugyan nem lehetne kitölteni egy szociolingvisztikai kérdőív első oldalán, a konkrét beszélői stratégiáira viszont mindenki ráismerhet (vö. Szilágyi N. i. h.).

A beszélői perspektíva „erejét” az adja, hogy olyan beszélő perspektíváját emeli be a leírásba, aki akár az utcán is szembe jöhetne velünk, sőt, szembe is jön, és bár hívják őt Jancsinak, Juliskának vagy másképp, magyar anyanyelvü beszélőként a határozatlan névelőt azonos vagy nagyon hasonló stratégiák alapján használja, mint mi. ${ }^{3}$

\section{A kutató perspektívája}

A leírás másik lehetséges perspektívája a kutatóé. Ez abban egyezik a beszélői perspektívával - legalább is a társas szemléletủ munkákban -, hogy szintén a beszélő beszédtevékenységének a jobb megértése a cél, de ennek eléréséhez a kutató egy az előzőtől teljesen eltérő stratégiát választ. Ebben az esetben a nyelvész „nem bújik a beszélő bőrébe”, és nem is „bújhat”, mert a kutatás tárgyától való távolságtartás olyan módszertani kritérium, amelynek a figyelmen kívül hagyása kétségbe vonhatná a kutatói munka hitelességét. ${ }^{4}$ A kutatásba való „bevonódásnak” ennél a perspektívánál több módszertani akadálya van, mint előnye. A kutatói perspektíva az empátia munkamódszerként való alkalmazása helyett, a kívülálló érdeklődését kínálja. Azonosulás helyett egyfajta felülnézetet, beleélés helyett tárgyiasítást - belátás helyett rálátást.

A kutatói perspektíva illusztrálásához Szabó Tamás Pétertől (2013: 380-396) választottam egy tanulmányt, amely egy szociolingvisztikai interjú tanulságait foglalja össze.

3 A beszélői perspektíva elkülönítése érdekes adalékot jelenthet a magyar idegen nyelvként való oktatásához. Érdemes feltenni a kérdést, hogy vajon nem növelné-e a kommunikációközpontú nyelvtanítás hatékonyságát, ha a nyelvi rendszert nem a grammatikai szabályok, hanem az anyanyelvi beszélők beszélői stratégiái szempontjából közelítenénk meg (vö. Misad 2011: 25).

4 Ezt a széles körben elfogadott nézetet kevesen vonták eddig kétségbe. A kivételek közé tartozik Bourdieu 1997: osz. n., 2003: 287; vö. Sebők 2017: 89. 
Arról szól, hogy az adatközlők különféle kategóriákba sorolása problémákba ütközik, mivel egyetlen adatközlő pozíciója egyetlen interjún belül is többször megváltozhat. A Szabó elemzéséből származó alábbi idézet is erről szól:

(2) Gábor az interjú végére megváltoztatta a saját pozícióját. Kezdetben azok közé sorolta magát, akik tudják, „hogy kell” beszélni, most pedig a javítást végző beszélőkből egy „ők-csoportot” képzett, akiktől elkülöníti magát. Azt a magatartást, amit korábban magára jellemzőként mutatott be, most elidegeníti magától; vö. (2): „csak megmondom neki, hogy hogy kell mondani” és (4): „azt mondja, hogy ö »én jobban tudom használni a szavakat, mint te"” (Szabó 2013: 392).

Ha a közölt szövegrészt összehasonlítjuk az előzővel (1. 1. példa), talán a legfeltűnőbb egyezés, hogy kutató az adatközlő keresztnevét használja, még ha - az adatvédelmi jogokkal összhangban - ez természetesen csak egy kitalált név is (vö. Szabó 2013: 387). A név tehát, az 1. példa Jancsijához hasonlóan, elképzelt, attól eltérően viszont egyetlen konkrét, azaz speciális szociolingvisztikai jellemzőkkel rendelkező egyénhez köthető, aki az interjúban szerepelt, és az adott körülmények között, időben, térben, valamilyen módon megnyilvánult.

Az 1. példában a nyelvész egy beszélőközösség beszélési stratégiáit jellemezte általános érvénnyel, és ezeket egy konkrét, mindenki által jól ismert élethelyzetben mutatta be egy olyan beszélőn keresztül, aki a beszélőközösség szinte bármelyik tagja lehetne. A 2. példában a kutató egy konkrét, létező személy beszédéről vont le következtetéseket - a saját maga által megszabott szempontok alapján, amelyeket az egész kutatásán végigvitt. A következtetések egy konkrét beszélőről szólnak, de a kutató azt feltételezi, hogy a vizsgált jelenség általánosabb érvényű, és más beszélők megvizsgálása után is hasonló eredményekre jutna. Azt viszont, hogy a megállapítások mennyire általános érvényủek, nem lehet tudni, és ehhez újabb kutatásokra van szükség.

Az alfejezet elején említett „távolságtartás” abban nyilvánul meg, hogy a kutató elsősorban az általánosabb érvénnyel bíró jelenségekre összpontosít, éppen ezért nem arra vonatkozólag von le következtetéseket, hogy a beszélö hogyan beszél, hanem azt a kérdést teszi fel, hogy mit csinál a beszélo" akkor, amikor beszél. „Pozíciót vált?”; „nyelvet használ?”; esetleg: „szociális struktúrát épít?”. A kutatás eredményei nagy mértékben attól függnek, hogy a kutató milyen ún. keretbe helyezi a kutatását, és milyen módszertani elveket határoz meg annak kiderítéséhez, hogy mi az, amit a beszélö beszéd közben csinál. Ha a kutató a nyelv használata iránt érdeklődik, akkor a nyelvi rendszer megvalósulását fogja nyomon követni a kutatása során, és azt írja le, hogy a beszélő hogyan használja azokat a szabályokat, amelyeket a nyelv szabályaiként tartunk számon. Ha a kutató a szociális struktúrák iránt érdeklődik, akkor valószínűleg azt fogja vizsgálni, hogy hogyan hozza ezeket létre a beszélő, amikor például megkérdezi valakitől, hogy mi újság. 
Összességében elmondhatjuk, hogy a kutató az, aki meghatározza a mintavétel körülményeit, kiválasztja az adatközlőket, felteszi a kutatás kérdéseit, és az adott fogalmi keretben, a begyűjtött adatok alapján válaszokat is ad ezekre. A kutató az, aki definiálja a fogalmakat, meghatározza a módszereket, és aki - fóleg a humán tudományokban - sokszor „megteremti” a kutatása tárgyát, illetve eldönti, hogy a vizsgálódásai során milyen magyarázó modellt választ. A sort pedig még tovább is lehetne folytatni. Ezen a ponton azonban azt fontosabb észrevenni, hogy ezek a tevékenységek a kutató „,világába” tartoznak. Vagyis: hogy olyan kérdésekről van szó, amelyek elsősorban a kutató perspektívájából fontosak és értelmesek, illetve olyan válaszokról, amelyek nem feltétlenül vannak összhangban a beszélőközösség belső világával (sőt, sokszor más kutatók világával sem). Ez pedig azt eredményezi, hogy a beszélők világában az 1. példával kapcsolatban említett aha-élmény nem következik be a kutatói perspektívából megfogalmazott válaszok hatására. ${ }^{5}$ A nyelvész fókusza ugyanis ebben az esetben áttolódott a beszélőkről a kutatásra, az eredmények pedig a kutatói perspektívából voltak megfogalmazva.

\section{A szerző perspektívája}

A harmadik megközelítés, amelyet szintén a nyelvészeti leírás egyik szervezőelveként tarthatunk számon, a szerző perspektívája. Ez egy olyan perspektívát jelent, amely az eredmények „közreadása” során mind a beszélői, mind a kutatói perspektívánál megjelenik. Ez az a perspektíva, amely alapján a nyelvész „írott formába önti” azokat a tapasztalatait, amelyekre a beszélők „beszélési stratégiáinak” a rekonstruálásával vagy egy kutatás elvégzésével tett szert; és ez az a perspektíva, amely nélkülözhetetlen elemét képezi a nyelvészeti leírásnak, függetlenül attól, hogy a közlésre szánt eredményekhez a beszélői vagy a kutatói perspektíván keresztül jutottunk-e el. De feltehetjük a kérdést: mit ad hozzá a szerzői perspektíva az előző két említett megközelítéshez?

Akár a beszélői, akár a kutatói perspektívát nézzük, a szerzői perspektíva a nyelvészeti vizsgálat egyfajta felülnézetét jelenti. A beszélői perspektíva esetében ez akkor nyilvánul meg, amikor a nyelvész egy történetbe foglalja a beszélés megfigyelt módját, a kutatói perspektíva esetében pedig akkor, amikor a kutató úgymond „rendet rak” az adatai között, és ezeket egy logikus, ellentmondásoktól mentes, koherens szöveggé szervezi, amely jól illeszkedik a feldolgozott téma kontextusába, és a nyelvészeti diszciplína valamely aktuális kérdésének a megértéséhez járul hozzá.

Alapvetően mindkét esetben a történetalkotáson van a hangsúly, csak míg a beszélői perspektívánál ez a történet az „átélt tapasztalatból” indul ki, addig a kutatói

5 Juraj Dolník (1997: 31-32) is hasonló következtetésre jutott a nyelvész (jazykovedec) és a hétköznapi nyelvhasználó (bežný použivatel' jazyka) összehasonlításával. Megállapította: a nyelvész egy globális rendszer szerint gondolkozik, a hétköznapi nyelvhasználó pedig lokális szinten. A kétféle rendszer általában nem feleltethető meg egymásnak. 
perspektívánál inkább a megfigyelés során „szerzett tapasztalatról” van szó. Mindkét perspektíva a történtek rekonstrukcióját jelenti (vö. Galasiński 2004: 132), csak míg az előbbi közvetlenül a beszélésről szól, addig az utóbbi elsősorban a kutatásról. Ez lényeges különbség, hiszen a kutatói perspektíva esetében a szerzőnek először a kutatásáról kell írnia ahhoz, hogy az eredményeket a beszélőre tudja vonatkoztatni. Azáltal, hogy a szerző a kutatás perspektíváján keresztül, vagyis közvetett módon ír a beszélőről, sokkal nagyobb tér nyílik az értelmezésre, mintha közvetlenül a beszélői perspektívából írna. A szerző teret kap arra, hogy azokat az elemeket emelje ki a kutatásából, amelyek a megfogalmazott feltevései szempontjából a legtöbb értelmet adják számára (Cameron 1995: 214). Az, hogy mi adja a legtöbb értelmet a számára, a feltett kérdésektől függ, hiszen a különböző kérdések különbözőképpen „világítják át” a kutatás eredményeit, és különbözőképpen változtatják meg a kutatás hangsúlyviszonyait. Ezt azért fontos megemlíteni, mert épp a hangsúlyviszonyok átrendezése teszi lehetővé a szerzőnek, hogy egyazon kutatásból többféle tanulmányt is írjon. Vagyis egyetlen kutatás többféle feldolgozásához épp a szerzői perspektívára van szükség.

Nagy a csábítás, hogy ezek után - Michel Foucault-ra (1991: 874-875, 1994: 42-75) hivatkozva - azt mondjuk, hogy a szerző tulajdonképpen nem más, mint a diskurzus rendezőelve. Nem is ez az azonosítás jelent problémát, hanem az, hogy Foucault a kutató perspektívájából, „kívülről” közelíti meg a meghatározást, és a szerzőt olyan rendezőelvnek tekinti, amelyet a kutató/kritikus alkot meg az adott szerző műveinek az értelmezéséhez. A mi szempontunkból viszont jobban megfelel, ha - a beszélői perspektívánál írottak alapján - a szerzo „bőrébe bújunk”, és megállapítjuk, hogy a szerző a saját gondolatainak, illetve kutatásának a „rendezőelve” - ő az, aki eldönti, hogy mit és hogyan tár az olvasó elé.

A szerzői perspektíva illusztrálásához nem kell messzire mennünk. Az tűnik a legjobb megoldásnak, ha az itt olvasható szöveget említem példaként, hiszen ennek a munkának a rendezőelveit ismerem a legjobban. ${ }^{6}$

Az itt olvasható munka során abból a korábbi megfigyelésemből indultam ki, hogy a metanyelv nem egyszerüen a nyelv : metanyelv fogalompár egyik fele, hanem egy olyan kategória, amelynek a jellege egyrészt attól függ, hogy mi az, ami a beszédről/nyelvről szóló beszéd tárgyát képezi, másrészt attól, hogy milyen perspektívából közelítjük meg a nyelv leírását. Négy perspektívát különböztettem meg: a beszélő, a kutató, a szerző és a terminusok perspektíváját. Összefoglaltam ${ }^{7}$ ezek fóbb jellemzőit a korábbi tapasztalataim

6 Ugyanakkor: nyelvészeti tanulmányok absztraktjait is megnézhetnénk példaként, hiszen nagyrészt ezek is azokról a „rendezőelvekről”, szerzői megfontolásokról szólnak, amelyek alapján az adott tanulmány készült.

7 A dolgozatnak ezen a pontján a múlt idő használata még nyilván nem egészen indokolt, hiszen az nem terjedhet ki a szöveg hátralévő részére. Az egyszerűség kedvéért mégis múlt időt használok, mert ez a „rendezőelvek” tisztázását egyáltalán nem befolyásolja, és mert fölösleges bonyolódáshoz vezetne, ha folyamatosan magyaráznom kellene azt, ami mindenki számára nyilvánvaló: hogy mely perspektívák leírása készült el eddig, és melyeké várható a továbbiakban. 
alapján, majd példákat kerestem ezek szemléltetésére. A példák elemzése további jellemzőkkel egészítette ki a leírást. Az összegyűjtött jellemzőket egy olyan sorrendbe rendeztem, amelyet mindegyik perspektíva jellemzésénél szem elött tartok. Ezek után a perspektívák sorrendjét határoztam meg. Abból indultam ki, hogy mindegyik perspektíva hátterében a beszélés jobb megértésének a szándéka húzódik, és a különbség ezek között abban áll, hogy mi az, amiről szólni akarunk, mi az, amit a mondandónk tárgyává teszünk, és hogy ezt „mennyi áttételen keresztül” valósítjuk meg: közvetlenül a beszélésről vagy egy modellált beszédhelyzetről írunk, esetleg felgyűjtött adatokról vagy egy kutatás eredményeiről, netán a terminusok viszonyairól? Ezt a megfontolást szem előtt tartva alakult ki a dolgozat struktúrája, amely különösen fontos a szerzői perspektíva szempontjából, hiszen a fejezetek sorrendje mellett ez határozza meg az egyes fejezetek jellegét is. A második fejezetet csak az első fejezetben írottakkal hasonlíthatjuk össze, a harmadik fejezet pedig szintén az első két fejezethez képest íródik. Ha más lenne a sorrend, mások lennének a dolgozat belső viszonyai is, máshol lennének a hangsúlyok, és ezáltal egy egészen más dolgozat születne. És akkor még nem beszéltünk a szöveg mikroszintjén jelentkező kisebb szerzői döntésekről, amelyek hozzávetőleges feldolgozása is egy külön dolgozatot igényelne. ${ }^{8} \mathrm{Az}$ azonban már ebből is jól látszik, hogy mi a szerzői perspektíva lényege, és hogy ez milyen fontos szerepet tölt be a metanyelv szerveződésében.

Összefoglalásképpen: a szerzőnek a leírás tárgyához való viszonyát az irodalomtudományból ismert fabula és szüzsé kapcsolatához hasonlítanám (erről l. Tomaševskij 1971: 193-208). Eszerint egy kutatáson alapuló tanulmány fabulája a kutatás. A mintavétel során szerzett adatok nem változnak, ahogy a kutatás kiindulópontjai és céljai sem. Az eredmények is adottak. Ami változik, az a kutatásról szóló eredmények feldolgozási módja - a kutatás szüzséje. Vagyis az, hogy a szerző mely eredményekre helyezi a hangsúlyt, milyen sorrendben közli az eredményeket, milyen megvilágításba helyezi ezeket, milyen leírói hagyományt követ - röviden: hogyan rekonstruálja a kutatását írásban.

\section{A terminusok „perspektívája”}

Ebben az alfejezetben egy az eddigiektől nagyobb mértékben eltérő megközelítéssel fogok foglalkozni - a terminusok „perspektívájával”. Az idézőjel arra utal, hogy míg az előző alfejezetekben olyan perspektívákról volt szó, amelyeket konkrét személyekhez - beszélőhöz, kutatóhoz, szerzőhöz - köthetünk, ebben az esetben egy élettelen dolgot személyesítek meg azáltal, hogy saját perspektívát tulajdonítok neki.

A beszélői perspektívát föntebb olyan megközelítésként írtam le, amelyen keresztül a nyelvész a beszélővel azonosul, és megpróbálja megfogalmazni a beszélés „stratégiáit”.

8 Bár nem tartozik a szorosan ide, mégis érdemes megemlíteni Edgar Allan Poe $A$ müalkotás filozófiája c. írását, amely rendkívül alapos betekintést nyújt $A$ holló c. művének írása közben alkalmazott „szerzői megfontolásokba”. 
A kutatói perspektíva esetében a nyelvész felülnézetből szemléli a beszélők tevékenységét, és egy kutatás „szűrőjén” keresztül írja le ezt. A szerző perspektíváját egy olyan perspektívaként mutattam be, amely egy még „távolabbi” rálátást enged a beszédtevékenységre a beszélés stratégiáinak, illetve a kutatás menetének a feldolgozásán keresztül. Ha pedig most áttérünk a terminusok „perspektívájára”, akkor egy olyan megközelítésről kell beszélnünk, amely az elözőkhöz képest sokkal távolabbra repít a beszélők valóságától. A terminusok „perspektívája” egy olyan megközelítést jelent, amely szerint a nyelvész a leírás során teljesen elhallgattatja (suppression) a beszélőt (erről l. Van Leeuwen: 1996: 39), figyelme pedig a nyelvi elemek tulajdonságaira korlátozódik. De nem csupán fokozati eltérésről, vagy: az áttételek számának a növeléséről van szó, hanem a leírás látószögének a megváltozásáról (vö. Dolník 2009: 35); egy olyan „szűrőről”, amely egészen különös módon láttatja a beszélők valóságát. Sőt, talán nem is helyénvaló a beszélők valóságát említeni, hiszen a terminusok perspektívájából nézve az már nagyon messze van, és nem is látszik igazán. Inkább egy elvont nyelvi valóság kialakításáról érdemes beszélnünk, amelynek mindegyik eleme „önálló életet él" (vö. Szilágyi 2011: 12-14).

A terminusok által alkotott elvont nyelvi valóság kérdéseivel három korábbi esettanulmányban foglalkoztam (Sebők 2014, 2016, 2020, összesítve 1. 2017: 113-143). Az első esettanulmányban egy saját, nyelvi ideológiákról írott szövegemen próbáltam nyomon követni, hogy hogyan változnak meg a nyelvi ideológia terminushoz kapcsolódó fogalmazásmódok, és hogy a terminus a szöveg mely részében válik cselekvővé. Vagyis: arra voltam kíváncsi, hogy a szöveg mely részében történik meg a váltás a kutató perspektívájáról a terminus perspektívájára.

A második esettanulmányban az igekötő terminushoz kapcsolódó fogalmazásmódokat vizsgáltam egy olyan szövegben, amelyben a perspektívaváltás már megtörtént, és a szöveg szerzője végig a terminusok perspektívájából szemlélteti a nyelvi valóságot. Az esettanulmányban egy olyan tendenciát mutattam ki, miszerint a terminusok amellett, hogy cselekvőként jelennek meg a szövegben, fokozatosan az ágens szerepét is átveszik. Ez azok után derült ki, hogy a terminus ,által végzett” cselekvések igéit az ágentivitás szempontjából elemeztem.

A harmadik esettanulmányban arra próbáltam rámutatni, hogy a terminusok „kompetenciabővülése” mellett, a különböző terminusok „kompetenciái” ki is egészítik egymást, mintha a terminusoknak előre meghatározott „szerepeik” lennének a nyelvi jelenség alakulásában. Ezek alapján arra a következtetésre jutottam, hogy a leírás metanyelve bizonyos szövegekben a terminusokra ruházott „szerepekről”, és az így megkonstruált „szereplőknek” a tetteiről szól.

Összességében tehát elmondhatjuk, hogy a terminusok „perspektívája” egy olyan elvont perspektívát takar, amelyen keresztül szemlélődve dologi valóságot tulajdonítunk az absztrakt fogalmaknak, és ezek viszonyait elemezve egy a beszélői valósággal párhuzamos nyelvi valóságot építünk. Egy olyan valóságot, amelyben a beszélők tevékenysége 
helyett a terminusok „tevékenységéről” van szó, és amelyben a terminusok leírt viszonyai alapján csak áttételesen lehet szemlélni a beszélők tevékenységét.

A terminusok „perspektívájának” a szemléltetéséhez egy a konferenciakötet témájához illő példát választottam az Uzonyi Kiss Judit által írott Magyar nyelv a 10. évfolyam számára c. tankönyvből:

(3) Az ige cselekvést, történést vagy létezést fejez ki úgy, hogy közben utal a cselekvő számára és személyére (igei személyragokkal), a cselekvés módjára (módjelekkel) és idejére (időjelekkel). Az ige jelentésénél fogva azt is megmutatja, hogy a cselekvés irányul-e valamire, vagy létrehoz-e valamilyen tárgyat vagy nem. Ugyancsak a jelentése révén azt is kifejezi, hogy a cselekvés lefolyásának ideje tartós vagy csak egy pillanatig tart. (Uzonyi Kiss 2009: 220, kiemelések az eredeti szövegben)

A szövegrészt valószínüleg minden alapiskolát végzett ember ismeri, és biztosan sokan akadnak közöttük, akik ezt a meghatározást, vagy ennek valamely változatát kívülről tudják. Szó szerint „kívülről”, mert az a perspektíva, amelyből ez megfogalmazódott, egyáltalán semmit sem árul el arról a „belso”” beszélői valóságról, amelynek a feltárását a többi perspektíva esetében feltételeztük. Ebben az esetben egy a beszédtevékenységgel párhuzamos nyelvi valóság kialakításáról van szó, amelyben a beszélők helyett a terminusok végzik a cselekvést.

Ha az idézetet összehasonlítjuk az 1-es és a 2-es példával, akkor a különbség már a szövegrészek legelején feltűnik: míg Szilágyi szövegében Jancsiról, Szabónál pedig Gáborról volt szó, addig Uzonyinál az ige van a figyelem középpontjában. Vagyis a személyek helyett itt a fókusz a terminusra került, a leírás ezért ebből a „perspektívából” folytatódik tovább. Ez alapján az ige különféle tevékenységeiről alkothatunk átfogó képet. Tételszerü leírást kapunk arról, hogy mi az, amit az ige „ki tud fejezni” és „meg tud mutatni”. A képet tovább árnyalja azoknak az eszközöknek a felsorolása, amelyekkel az ige elvégzi ezeknek a tevékenységeknek egy részét. Azt pedig, hogy mire irányulnak az említett tevékenységek, egy további felsorolásból tudjuk meg. A terminusok jellemzőinek egy részével szintén a tankönyvből ismerkedhetünk meg, ami még tovább vezet bennünket a terminusoknak a beszédtevékenységgel párhuzamosan létező világában. Kiderül például, hogy már a nevükben is „cselekvo”” igéknél a cselekvést tulajdonképpen nem is az ige végzi, hanem az alany saját maga, mi több, „ha valamire irányul ez a cselekvés, az nem önmaga az alany” (Uzonyi Kiss i. h.). A meghatározás három alcsoport elkülönítésével folytatódik, az elemzést viszont nem folytatom tovább (de vö. Misad 2020, ebben a kötetben). Ennyiből is jól látszik, hogy a leírás alapvetően különböző terminusok kapcsolatairól és cselekedeteiről szól, amelyekből a diák azt a párhuzamos valóságot ismerheti meg, amely a nyelvtankönyv tárgyát képezi, és amelyre a tankönyv címében „magyar nyelv”-ként utalnak. 
A terminusok „perspektíváján” keresztül tehát a nyelvész - vagy adott esetben: a nyelvtankönyvíró - a terminusokra, illetve a köztük lévő viszonyokra irányítja rá a figyelmet. Nincs elképzelt vagy valódi beszélö, ehelyett terminusokba tömörített elvonatkoztatások vannak a maguk törvényszerűségeivel. Ezek a törvényszerűségek csak áttételesen vezethetők vissza a beszélők világába, de ha ez meg is történik, kétségkívül felmerül a kérdés, hogy vajon hitelesek lehetnek-e azok az eredmények a beszélők világában, amelyek a terminusok párhuzamos világában születtek.

\section{Zárszó}

Dolgozatomban a metanyelv kérdésével foglalkoztam, és abból indultam ki, hogy ez az általában nyelvről szóló nyelvként jellemzett kategória jóval összetettebb jelenség, mint azt a meghatározása sugallja. A metanyelv nemcsak azért érdekes, mert egy olyan beszéd- vagy írásmódot takar, amelynek tárgya/témája a nyelv, hanem mert ez is egyfajta beszéd, amelynek a jellege nagyban befolyásolja a nyelvleírást. Foucault-t felemlegetve: az, hogy hogyan beszélünk a nyelvről, nagyban befolyásolja, hogy hogyan fogunk gondolkodni a nyelvről; az pedig, hogy hogyan gondolkodunk a nyelvről, meghatározza, hogy hogyan fogunk erről beszélni (vö. Dolník 2010: 237). Ezért érdemes foglalkozni azzal a kérdéssel, hogy milyen az a beszédmód, amely a beszédről vagy a nyelvről szól.

Ebben a munkámban a kérdést a leírás különböző perspektíváinak a jellemzése felől közelítettem meg. Elkülönítettem a beszélő, a kutató, a szerző és a terminusok perspektíváját mint a leírás különböző szervezőelveit. Abból a feltevésből indultam ki, hogy valahol mindegyik perspektíva a beszélő tevékenységének a jobb megértését tűzi ki céljául, de ezekhez más-más leírói stratégiák kapcsolódnak, amelyek föleg abban különböznek egymástól, hogy mennyi áttétellel teszik lehetővé a beszédtevékenység megismerését. Vagy másképp ugyanez: mennyire rugaszkodnak el a hétköznapi beszéd valóságától.

Azt a perspektívát, amely a legkevésbé távolodik el a beszélők valóságától, sőt megpróbál ezzel azonosulni, beszélői perspektívának neveztem. Ebből a perspektívából nézve minden nyelvészeti kutatásnak egyetlen kérdés köré kellene összpontosulnia: hogy az miben járul hozzá a beszédtevékenység jobb megértéséhez? A (társas) nyelvész kutatói perspektíváját olyan megközelítésként foglalnám össze, amely során a nyelvész - „ellenőrzött” körülmények között - egyfajta felülnézetből foglalkozik a beszélők tevékenységével. Valamilyen módszertani „szűrőn” keresztül közelíti meg a beszédtevékenységet, és az így szerzett adatok elemzésére alapozza a megállapításait. A szerző perspektíváját azért fontos elkülöníteni, hogy egyértelművé váljon: a leírás - függetlenül attól, hogy kutatáson alapul-e - mindig egyfajta rekonstrukciója a beszélői valóságnak. Végül: a terminusok perspektívája egy olyan megközelítést takar, amely a beszédtevékenység egyes mozzanatait terminusok közötti viszonyokkal értelmezi. 
Ez utóbbi perspektíva sokszor nagyon praktikus (hiszen így hosszú magyarázatokat lehet néhány szóban összefoglalni), mégis úgy tűnik, hogy a leírás ilyen módját inkább mintegy járulékos elemként érdemes kezelni. Ellenkező esetben a beszélők valóságával kapcsolatos áttételek elhomályosulnak, és a perspektíva egy párhuzamos, elvont nyelvi valóság kialakításának az eszközévé válik.

A leírás négy perspektívájának az elkülönítése több puszta elméleti érdekességnél. Ezek azonosítása ugyanis hasznos kiindulópont lehet egyes nyelvi problémák kezelésénél. Feltehetjük a kérdést, hogy vajon egyes nyelvi vagy nyelvészeti problémák megoldása nem azon alapul-e, hogy ezeket nem a megfelelő perspektívából szemléljük. Vajon a klasszikus értelemben vett nyelvmüvelés problémája nem azon alapul-e, hogy a nyelvész problémáit a beszélők problémáiként állítja be; és a napjainkban megerősödött nyelvmenedzselés sikere vajon nem abban gyökerezik-e, hogy megfordította a két perspektívát, és a beszélők problémáit a nyelvész problémáiként kezdte kezelni. Vagy: nem abban rejlik-e a tantervek megreformálásának a problémája, hogy az oktatás problémáit a tantervek terminológiájának a megváltoztatásával akarják megoldani? És vajon nem lenne-e jobb, ha a terminusok „perspektívája” helyett a beszélo” vagy a kutató perspektívája jelenne meg a diákok tankönyveiben? A kérdések némileg sugallják a rájuk adható feltételezett válaszokat. Ezek tisztázása azonban még további kutatások tárgyát fogja képezni.

\section{Források}

Uzonyi Kiss Judit 2009. Magyar nyelv a 10. évfolyam számára. Celldömölk: Apáczai Kiadó.

\section{Irodalom}

Bourdieu, Pierre 1997. A közvélemény nem létezik. Szociológiai Figyelö 13/1-2: 136-145. Bourdieu, Pierre 2003. Participant objectivation. Journal of the Royal Anthropological Institute 9: 281-294. https://doi.org/10.1111/1467-9655.00150

Cameron, Deborah 1995. Stories of language. In: Cameron, Deborah: Verbal hygiene. London, New York: Routledge. 212-215.

Coupland, Nikolas - Jaworski, Adam 2004. Sociolinguistic perspectives on metalanguage: Reflexivity, evaluation and ideology. In: Jaworski, Adam - Coupland, Nikolas Galasiński, Dariusz (eds.): Metalanguage: Social and ideological perspectives. Berlin, New York: Mouton de Gruyter. 15-51.

Crystal, David 2008. Dictionary of linguistics and phonetics. Malden, Oxford, Melbourne, Berlin: Blackwell Publishing. 
Dolník, Juraj 2009. Všeobecná jazykoveda. Opis a vysvetl’ovanie jazyka. Bratislava: Veda Jazykovedný ústav Ludovíta Štúra SAV.

Dolník, Juraj 2010. Teória spisovného jazyka so zretelom na spisovnú slovenčinu. Bratislava: Veda.

Foucault, Michel 1991. A diskurzus rendje. Holmi 7: 868-889.

Foucault, Michel 1994. Co je to autor? In: Horák, Petr (szerk.): Diskurs, autor, genealogie. Praha: Nakladatelství Svoboda. 42-75.

Gal, Susan 2006. Migration, minorities and multilingualism: Language ideologies in Europe. In: Mar-Molinero, Clare - Stevenson, Patrick (eds.): Language ideologies, policies and practices. Language and the future of Europe. Basingstoke: Palgrave, Macmillan. 13-27. https://doi.org/10.1057/9780230523883_2

Galasiński, Dariusz 2004. Restoring the order: Metalanguage in the press coverage of Princess Diana's Panorama interview. In: Jaworski, Adam - Coupland, Nikolas Galasiński, Dariusz (eds.): Metalanguage: Social and ideological perspectives. Berlin, New York: Mouton de Gruyter. 131-145.

Jakobson, Roman 1956/1985. Metalanguge as a linguistic problem. In: Selected writings VII. Berlin: Mouton de Gruyter. 113-121.

Jaworski, Adam - Coupland, Nikolas - Galasiński, Dariusz 2004. Metalanguage: Why now? In: Jaworski, Adam - Coupland, Nikolas - Galasiński, Dariusz (eds.): Metalanguage: Social and ideological perspectives. Berlin, New York: Mouton de Gruyter. 3-8. https://doi.org/10.1515/9783110907377

Jørgensen, Jens Normann - Karrebæk, Martha Sif - Madsen, Lian Malai - Møller, Janus Spindler 2011. Polylanguaging in superdiversity. Diversities 13/2: 23-37.

Lanstyák István 2014. Nyelvalakitás és nyelvi ideológiák. Bratislava: Univerzita Komenského v Bratislave.

Lanstyák István 2017. Nyelvítés. In: Gróf Annamária - Kolláth Anna - Szoták Szilvia (szerk.): Szélrózsa. A Termini Magyar Nyelvi Kutatóhálózat 2014. évi lendvai konferenciájának anyaga. Budapest: Termini Egyesület. 49-50.

Misad Katalin 2011. Kapitoly z morfológie mad'arského jazyka. Kontrastivny opis niektorých morfologických javov mad'arského jazyka. Bratislava: Univerzita Komenského $\mathrm{v}$ Bratislave.

Misad Katalin 2020. A nyelvváltozatok szemléltetése a szlovákiai magyar tannyelvű iskolák anyanyelvtankönyveiben. In: Ludányi Zsófia - Jánk István - Domonkosi Ágnes 2020 (szerk.): A nyelv perspektivája az oktatásban. Válogatás a PeLiKon2018 oktatásnyelvészeti konferencia elöadásaiból. Eger: Líceum Kiadó. 251-260.

Mistrík, Jozef et al. 1993. Encyklopédia jazykovedy. Bratislava: Obzor.

Preston, Dennis R. 2004. Folk metalanguage. In: Jaworski, Adam - Coupland, Nikolas - Galasiński, Dariusz (eds.): Metalanguage: Social and ideological perspectives. Berlin, New York: Mouton de Gruyter. 75-101. 
Sebők Szilárd 2014. Mit tehet az igekötő? In: Misad Katalin - Csehy Zoltán (szerk.): Nova Posoniensia IV. A pozsonyi magyar tanszék évkönyve. Pozsony: Szenczi Molnár Albert Egyesület - Kalligram Kiadó. 80-95.

Sebők Szilárd 2016. Fogalmazásmód-változások a terminushasználatban (egy szövegen belül). In: Kozmács István - Vančo Ildikó (szerk.): Standard - Nem standard. Variációk egy nyelv változataira. Válogatás a 18. Élönyelvi Konferencia elöadásaiból. Lakitelek: Antológia Kiadó. 101-114.

Sebők Szilárd 2017. Meta és nyelv. Kisérletek a nyelvleirás nyelvének leirására. Pozsony: Univerzita Komenského v Bratislave.

Sebők Szilárd 2020. Dynamika používania lingvistických termínov? In: Gajdošová, Katarína - Peter Gregorík (eds.): VARIA XXIII. Zbornik prispevkov z XXIII. kolokvia mladých jazykovedcov. 255-263.

Smullyan, Raymond M. 1986. Jak se jmenuje table knižka? Praha: Mladá fronta.

Szabó Tamás Péter 2013. Egy megfigyelés - több interpretáció. In: Kontra Miklós Németh Miklós - Sinkovics Balázs (szerk.): Elmélet és empiria a szociolingvisztikában: Válogatás a 17. Élönyelvi Konferencia elöadásaiból. Budapest: Gondolat Kiadó. 380-396.

Szilágyi N. Sándor 2004. Az absztraktumok csapdája. In: Szilágyi N. Sándor: Elmélet és módszer a nyelvészetben különös tekintettel a fonológiára. Kolozsvár: Erdélyi MúzeumEgyesület. 10-40.

Szilágyi N. Sándor 2011. Szinkrónia és diakrónia - de miről is beszélünk? In: Kádár Edit - Szilágyi N. Sándor (szerk.): Szinkronikus nyelvleirás és diakrónia. Kolozsvár: Erdélyi Múzeum-Egyesület. 9-30.

Szilágyi N. Sándor 2013. A mi (rend)szertelen nyelvünk. In: Kádár Edit - Szilágyi N. Sándor (szerk.): Analógia és modern nyelvleirás. Kolozsvár: Erdélyi MúzeumEgyesület. 235-263.

Tomaševskij, Boris 1971. Sujetová stavba. In: Poetika. Teória literatúry. Bratislava: Smena. 189-228.

Tóth Péter 2007. A gondolkodásfejlesztés gyakorlata az informatikaoktatásban I. Szakképzési Szemle 23/3: 249-274.

Van Leeuwen, Theo 1996. The representation of social actors. In: Coulthard Caldas, Carmen Rosa - Coulthard, Malcolm (eds.): Texts and practices. Readings in critical discourse analysis. London: Routledge. 32-70.

Woodworth, Robert S. - Schlosberg, Harold 1959. Experimentálna psychológia. Bratislava: Slovenská akadémia vied. 